\title{
(2) SOFT TISSUE RESPONSE AFTER MAXILLARY STEP SURGERY WITH OR
WITHOUT ANS REDUCTION
}

ABSTRACT

Objectives: Prediction of the soft tissue profile is an important part of orthognathic surgery planning. Variations in surgical techniques can affect soft tissue response. The current study aimed to determine the effects of maxillary step osteotomy with or without anterior nasal spine (ANS) reduction on the soft tissue response.

Materials and Methods: A total of 24 patients (17 women, 7 men) who underwent maxillary advancement and mandibular set back surgery using maxillary step and bilateral sagittal split ramus osteotomy techniques were included in the study. Then two subgroups were created as ANS reduction positive group (ANSR+) and negative group (ANSR-). Cinch suture and $\mathrm{V}-\mathrm{Y}$ closure techniques were used in all patients. The lateral cephalometric radiographs which had taken preoperatively and 6-8 months after surgery were recruited. Soft and hard tissue changes were evaluated by using paired samples T-test. Pearson correlation test was used to determine the correlation between hard and soft tissue movements.

Results: Maxillary soft to hard tissue ratios of the ANSR+ group were lower than those in the ANSR-group. The ratios were Pr/ANS: 6\% vs 49\%, Pr/A: $16 \%$ vs $42 \%, \mathrm{Sn} / \mathrm{A}: 52 \%$ vs $66 \%$, Ls/U1: $31 \%$ vs $78 \%$, in ANSR+ and ANSR-groups, respectively.

Conclusions: The maxillary step osteotomy technique may be useful in patients where it is desired to further support the nose tip in an anterior direction. ANS reduction process causes a quite decrease in the soft tissue response of the tip of the nose and the upper lip. The subnasal region is relatively less affected.

Keywords: Orthodontics, orthognathic surgical procedures, cephalometry.
Neslihan İzgi ${ }^{1}$

*Sibel Akbulut ${ }^{1}$

Nihat Akbulut ${ }^{2}$

ORCID IDs of the authors:

N.I. $\quad$ 0000-0002-1469-9161

S.A. $\quad 0000-0003-3007-1179$

N.A. $\quad$ 0000-0001-6950-8214

1 Gaziosmanpasa University Faculty of Dentistry, Department of Orthodontics, Tokat/Turkey.

2 Gaziosmanpasa University Faculty of Dentistry, Department of Oral and Maxillofacial Surgery, Tokat/Turkey.

Received : : 14.10 .2020

Accepted $\quad: 15.02 .2021$

How to Cite: İzgi N, Akbulut S, Akbulut N. Soft Tissue Response after Maxillary Step Surgery with or without ANS Reduction. Cumhuriyet Dent J 2021;24:1:

Kaleardı Street, Ali Sevki Erek Yerleskesi, Tokat Gaziosmanpasa University Faculty of Dentistry, Department of Orthodontics, 60100, Tokat / Turkey.

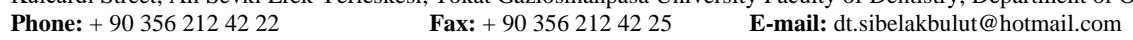




\section{INTRODUCTION}

Orthognathic surgery is a method in the treatment of skeletal deformities in adults. The goal of orthognathic surgery is an improved facial aesthetic with a functional occlusion. ${ }^{1,2}$ Therefore, it is essential for the clinician to accurately predict the soft tissue profile after surgery. Although there are many studies on this subject, many different rates have been reported, especially for the maxillary region. In the literature, the reason for that shown as variations in surgical techniques used in the maxilla. ${ }^{3}$ Variations in surgical techniques can affect the soft tissue response. ${ }^{4,5}$ In a recent study $^{4}$ even adjunctive procedures such as $\mathrm{V}-\mathrm{Y}$ closure and alar base cinch suture have been reported to cause alterations on related soft tissue response. Unfortunately, many studies ${ }^{6-8}$ in the literature did not report detailed information about the osteotomy type or the soft tissue techniques used. Therefore, there is a need for studies classified according to each surgical factors such as type of the osteotomy technique, applied soft tissue procedures, or magnitude and direction of surgical movements. $^{3}$

The original Le Fort I osteotomy may be sufficient for mild or moderate midface deficiency correction, especially as an aesthetic approach. ${ }^{9}$ Severe midface deficiency has been corrected by using quadrangular Le Fort I osteotomy..$^{10}$ Also, some stabilization problems were seen in the original Le Fort I osteotomy. So, less invasive and more stable techniques were searched and developed in later studies. ${ }^{11-13}$ The maxillary step technique was firstly described by Bennett and Wolford $^{14}$ in 1985 to overcome these disadvantages of the original Le Fort I osteotomy. Later, many modifications were made, and these continue to be used. ${ }^{9}{ }^{15}$ The studies have shown that maxillary step osteotomy and its modifications are more stable than the original Le Fort I osteotomy.

Although there is a tendency for threedimensional (3D) planning today, reasons such as cost, time investment, and learning curve hamper the $3 \mathrm{D}$ planning to enter the routine practice. ${ }^{16}$ Moreover, the lateral cephalograms are very useful and feasible in the sagittal profile examination with a low radiation dose. So, this retrospective study aimed to investigate the effects of maxillary step osteotomy technique with and without ANS reduction on the soft tissue response using lateral cephalometric radiographs.

\section{MATERIAL AND METHODS}

Ethical approval was granted by the clinical research ethics committee of the Tokat Gaziosmanpasa University (Project number: 19KAEK-111). The study included 24 patients with skeletal Class III malocclusion who received orthodontic treatment at Tokat Gaziosmapasa University, Department of Orthodontics, and operated in Oral and Maxillofacial Surgery Department of the same university. The mean age of the patients ( 17 women, 7 men) was $21.6 \pm 4.72$ years.

The following criteria were used as inclusion criteria;

- Patients who underwent maxillary advancement and mandibular set back surgery without maxillary impaction

- Patients who have lateral cephalometric radiographs with adequate quality, taken just before surgery and 6-8 months after surgery

Exclusion criteria were as follows:

- Patients with a maxillary vertical movement bigger than $3 \mathrm{~mm}$

- Patients who underwent additional surgical interventions such as genioplasty or infraorbital augmentation

- $\quad$ Facial asymmetry patients with occlusal cants in the frontal plane

- Patients with any craniofacial anomaly such as cleft lip and palate

- Patients previously underwent surgical procedures related to maxilla or mandible

Maxillary movements were planned parallel to the Frankfurt horizontal plane, and surgical splints were constructed by using model surgery. Mandibular movements were planned to accommodate maxillary occlusion.

All patients underwent bimaxillary orthognathic surgery by the same surgical team. The maxillary step osteotomy technique ${ }^{14}$ was performed in all patients (Figure 1). 


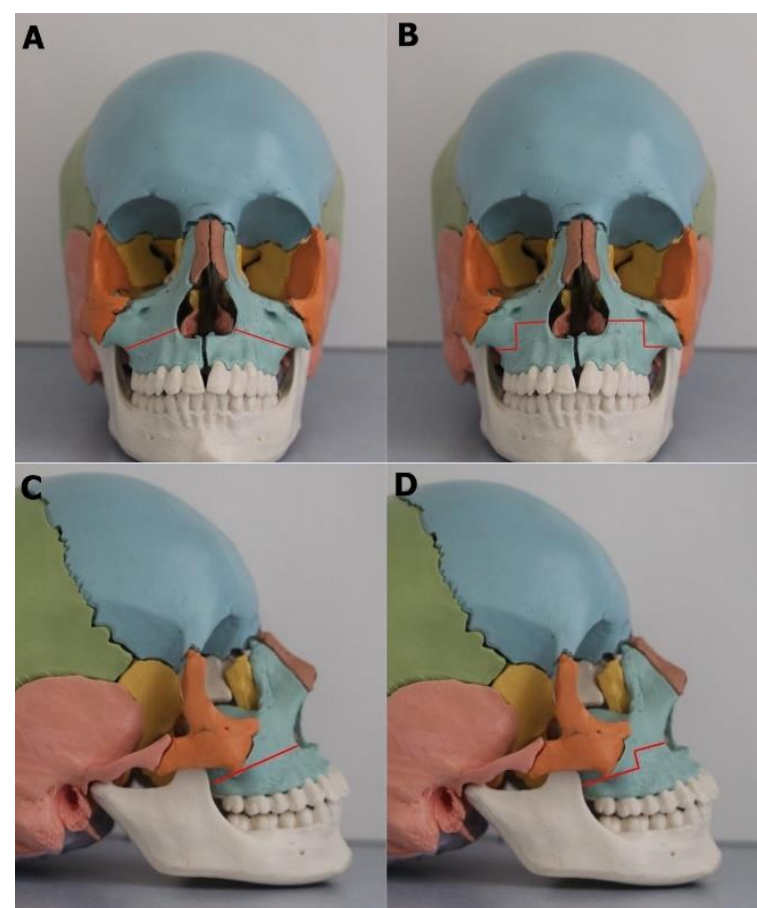

Figure 1: Illustration of the difference between the maxillary step osteotomy line and the original Le Fort I osteotomy (A) Frontal view of the original Le Fort I osteotomy. (B) Frontal view of the maxillary step osteotomy. (C) Lateral view of the original Le Fort I osteotomy. (D) Lateral view of the maxillary step osteotomy.

Then the maxilla was mobilized and repositioned according to the presurgical plan. Fixation was performed via monocortical plates and screws. Under the surgery plan, ANS reduction was performed in 12 of 24 patients (ANSR+ group), while ANS was kept intact in the remaining 12 patients (ANSR- group). Cinch suture ${ }^{17}$ and V-Y closure $^{18}$ techniques were used in all operations. The cinch suture was performed using a $2 / 0$ absorbable suture and a curved needle. The suture was passed through the lateral nasal muscles and their fibroareolar tissues in a lateral to medial direction. Then, the suture was tied for the approximation of the alar bases and fixed to a hole made in the anterior nasal spine.

Mandibular surgery was performed by bilateral sagittal split ramus (BSSR) osteotomy technique in all patients. Monocortical plates and bicortical screws were used for mandibular fixation. Demonstrative presentation of a patient included in the study was shown in Figure 2.
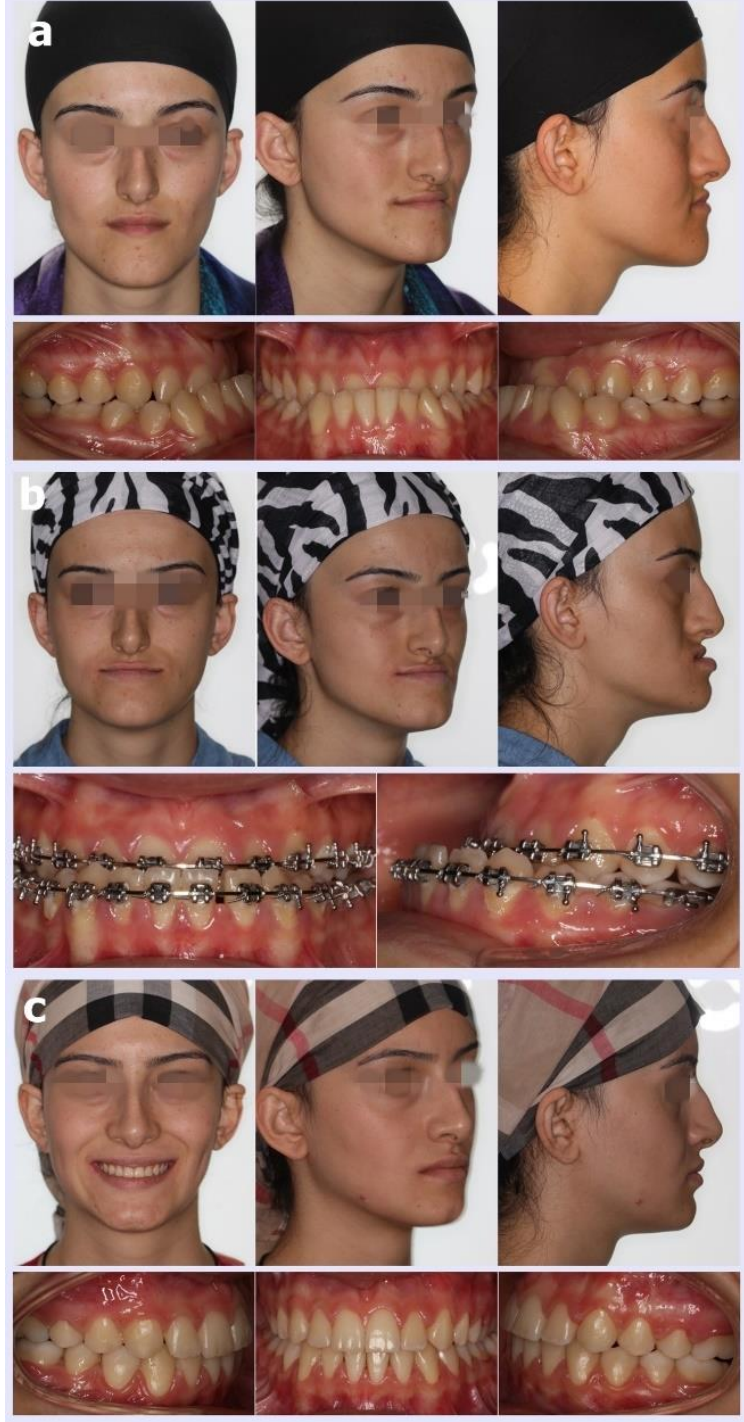

Figure 2: Extraoral and intraoral photographs of a patient included in the study. a: At the beginning of the orthodontic treatment, b: Preoperative, c: At the end of the treatment.

All lateral cephalometric radiographs were traced using Dolphin Imaging software (Version 11.5, Patterson Dental, CA, USA) by a single examiner (NI). The cephalometric radiographs were evaluated using a modified Legan-Burstone soft tissue analysis method. ${ }^{19,20}$ With this method, a horizontal reference line was constructed raised + $7^{\circ}$ from Sella-Nasion, and a perpendicular line from the Nasion point was used as the vertical reference (Figure 3). 


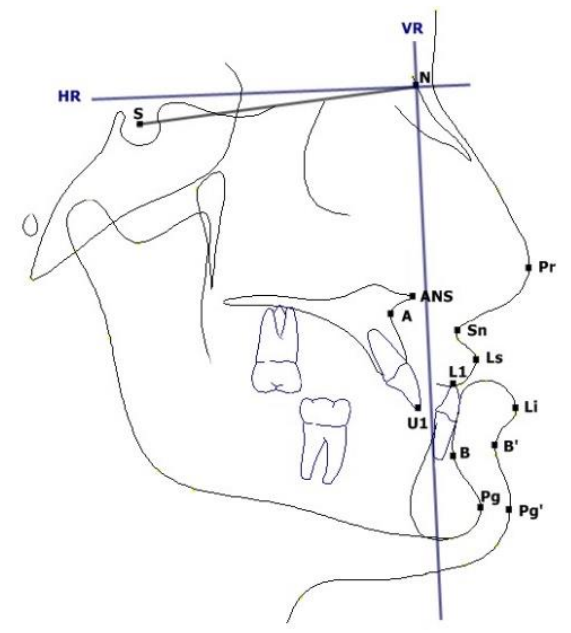

Figure 3: Cephalometric landmarks and reference planes: $S$ indicates Sella, N: Nasion, ANS: anterior nasal spine, A: point A, U1: maxillary incisor tip, L1: mandibular incisor tip, B: point B, Pg: hard tissue pogonion, Pr: pronasale, Sn: subnasale, Ls: upper lip, Li: lower lip, B': soft tissue B point, and Pg': soft tissue pogonion, HR: horizontal reference line, VR: vertical reference line.

The measured soft tissue landmarks were pronasale $(\mathrm{Pn})$, subnasale (Sn), labrale superior (Ls), labrale inferior (Li), soft tissue B point (B'), and soft tissue Pogonion (Pog'). And the hard tissue landmarks were anterior nasal spine (ANS), point A (A), upper incisor tip (U1), lower incisor tip (L1), B point (B), and pogonion (Pog). The distances of hard and soft tissue landmarks to the vertical reference line were measured on pre- and postsurgical cephalograms. The differences were recorded as the amount of soft or hard tissue movements.

Three weeks later, to assess the repeatability of the measurements, pre- and postoperative lateral cephalograms of 9 patients who were randomly selected were retraced by the same researcher.

\section{Statistical Analysis}

Statistical analysis of the data was carried out using the SPSS statistical software package (SPSS Inc. version 19.0) (IBM, Somers, NY, USA). The means, standard deviations, and differences between time points were calculated. The changes between time points were analyzed with paired samples T-test. Pearson correlation test was used to evaluate the correlations between soft and hard tissue parameters. Dahlberg ${ }^{21}$ formula $\sqrt{ }\left(\Sigma \mathrm{d}^{2} / 2 \mathrm{n}\right)$ was used to assess intraexaminer repeatability. The level of significance was set at $\mathrm{P}<0.05$.

\section{RESULTS}

The intraexaminer reliability was high with an error of $\leq 0.34 \mathrm{~mm}$ in linear measurements, and an error of $\leq 0.24^{\circ}$ in angular measurements.

The mean and standard deviations of the measurements and the changes between time points of all patients were given in Table 1.

Table 1. The cephalometric changes after orthognathic surgery in all included patients

T1

\begin{tabular}{|c|c|c|c|c|c|c|c|}
\hline & Mean & SD & Mean & SD & Mean & SD & $\mathrm{p}$ \\
\hline SNA $\left({ }^{\circ}\right)$ & 78.82 & 6.03 & 82.68 & 5.7 & 3.86 & 1.95 & $0.00 *$ \\
\hline $\mathrm{SNB}\left({ }^{\circ}\right)$ & 84.33 & 5.59 & 81.92 & 5.49 & -2.4 & 1.52 & $0.00 *$ \\
\hline ANB $\left({ }^{\circ}\right)$ & -5.51 & 2.8 & 0.77 & 2.43 & 6.28 & 2.1 & $0.00 *$ \\
\hline Wits (mm) & -13.06 & 3.76 & -4.42 & 3.11 & 8.64 & 2.98 & $0.00 *$ \\
\hline Overjet (mm) & -7.27 & 2.82 & 2.85 & 0.96 & 10.13 & 2.55 & $0.00 *$ \\
\hline Overbite (mm) & 1.31 & 2.64 & 1.75 & 1.2 & 0.44 & 2.47 & 0.39 \\
\hline Nasolabial angle $\left(^{\circ}\right)$ & 103.66 & 9.89 & 104.29 & 9.5 & 0.62 & 6.72 & 0.65 \\
\hline Mentolabial angle $\left({ }^{\circ}\right)$ & 142.03 & 12.27 & 135.22 & 11.73 & -6.8 & 11.06 & $0.01 *$ \\
\hline ANS-VR(mm) & 0.72 & 6.52 & 4.15 & 5.43 & 3.42 & 2.48 & $0.00 *$ \\
\hline $\mathrm{A}-\mathrm{VR}(\mathrm{mm})$ & -4.4 & 6.48 & -0.26 & 5.63 & 4.14 & 1.93 & $0.00 *$ \\
\hline U1-VR (mm) & -0.37 & 8.31 & 5.02 & 8.02 & 5.4 & 2.55 & $0.00 *$ \\
\hline L1-VR (mm) & 6.89 & 8.74 & 2.44 & 7.71 & -4.45 & 3.22 & $0.00 *$ \\
\hline $\mathrm{B}-\mathrm{VR}(\mathrm{mm})$ & 1.95 & 10.26 & -1.76 & 9.41 & -3.72 & 3.44 & $0.00 *$ \\
\hline Pg-VR (mm) & 4.69 & 11.35 & 1.96 & 10.43 & -2.72 & 4 & $0.00 *$ \\
\hline Pr-VR (mm) & 29.08 & 4.85 & 30.51 & 4.54 & 1.42 & 1.51 & 0.00* \\
\hline Sn-VR (mm) & 13.36 & 5.87 & 15.95 & 5.4 & 2.58 & 2.03 & $0.00 *$ \\
\hline Ls-VR (mm) & 14.28 & 7.71 & 17.58 & 7.21 & 3.3 & 2.95 & $0.00 *$ \\
\hline
\end{tabular}


$\dot{I z} g i \mathrm{~N}$, et al.

\begin{tabular}{lccccccc}
$\mathrm{Li}-\mathrm{VR}(\mathrm{mm})$ & 19.41 & 9.44 & 15.62 & 8.67 & -3.79 & 4.01 & $\mathbf{0 . 0 0} *$ \\
B'-VR(mm) & 13.06 & 10.49 & 9.32 & 9.76 & -3.74 & 3.63 & $\mathbf{0 . 0 0} *$ \\
Pg'-VR $(\mathrm{mm})$ & 15.34 & 11.29 & 12.5 & 10.36 & -2.84 & 4.18 & $\mathbf{0 . 0 0} *$ \\
\hline
\end{tabular}

Statistically significant increase in overjet, ANB, SNA, and Wits; a significant decrease in SNB and mentolabial angle were found $(\mathrm{p}<0.05)$. There was no statistically significant change in the overbite and nasolabial angle. The advancement amount of point A, U1-tip, and ANS were found to be $4.14 \pm 1.93 \mathrm{~mm}, 5.4 \pm 2.55 \mathrm{~mm}$, and $3.42 \pm 2.48 \mathrm{~mm}$, respectively. The amounts of setback were $3.72 \pm 3.44 \mathrm{~mm}$ at point $\mathrm{B}, 4.45 \pm 3.22 \mathrm{~mm}$ at L1-tip, and $2.72 \pm 4 \mathrm{~mm}$ at Pog.

The cephalometric differences between ANSR+ and ANSR-groups in different time points were given in Table 2 .

Table 2. The maxillary cephalometric differences between ANSR+ and ANSR-groups

\begin{tabular}{|c|c|c|c|}
\hline & $\begin{array}{c}\text { ANSR+ } \\
\text { Mean } \pm \text { SD }\end{array}$ & $\begin{array}{c}\text { ANSR- } \\
\text { Mean } \pm \text { SD }\end{array}$ & p \\
\hline \multicolumn{4}{|l|}{ ANS-VR } \\
\hline $\mathrm{T} 1$ & $0.86 \pm 5.60$ & $0.60 \pm 7.59$ & 0.92 \\
\hline $\mathrm{T} 2$ & $3.19 \pm 5.00$ & $5.12 \pm 5.90$ & 0.40 \\
\hline $\mathrm{T} 2-\mathrm{T} 1$ & $2.33 \pm 2.01$ & $4.52 \pm 2.51$ & $0.02 *$ \\
\hline \multicolumn{4}{|l|}{ A-VR } \\
\hline T1 & $-3.91 \pm 5.32$ & $-4.90 \pm 7.68$ & 0.72 \\
\hline $\mathrm{T} 2$ & $-0.38 \pm 4.82$ & $-0.14 \pm 6.56$ & 0.92 \\
\hline $\mathrm{T} 2-\mathrm{T} 1$ & $3.52 \pm 1.54$ & $4.76 \pm 2.16$ & 0.12 \\
\hline \multicolumn{4}{|l|}{ U1-VR } \\
\hline T1 & $0.97 \pm 7.41$ & $-1.72 \pm 9.26$ & 0.44 \\
\hline $\mathrm{T} 2$ & $6.33 \pm 7.07$ & $3.72 \pm 9.00$ & 0.44 \\
\hline $\mathrm{T} 2-\mathrm{T} 1$ & $5.36 \pm 2.39$ & $5.44 \pm 2.83$ & 0.94 \\
\hline \multicolumn{4}{|l|}{ Pr-VR } \\
\hline T1 & $29.13 \pm 5.20$ & $29.04 \pm 4.72$ & 0.96 \\
\hline $\mathrm{T} 2$ & $29.95 \pm 4.59$ & $31.07 \pm 4.62$ & 0.55 \\
\hline $\mathrm{T} 2-\mathrm{T} 1$ & $0.82 \pm 1.11$ & $2.03 \pm 1.66$ & 0.04* \\
\hline \multicolumn{4}{|l|}{ Sn-VR } \\
\hline $\mathrm{T} 1$ & $13.94 \pm 6.09$ & $12.78 \pm 5.87$ & 0.64 \\
\hline $\mathrm{T} 2$ & $15.99 \pm 5.09$ & $15.91 \pm 5.92$ & 0.97 \\
\hline $\mathrm{T} 2-\mathrm{T} 1$ & $2.05 \pm 1.61$ & $3.12 \pm 2.33$ & 0.20 \\
\hline \multicolumn{4}{|l|}{ Ls-VR } \\
\hline T1 & $15.42 \pm 7.39$ & $13.16 \pm 8.19$ & 0.49 \\
\hline $\mathrm{T} 2$ & $17.91 \pm 6.54$ & $17.27 \pm 8.11$ & 0.83 \\
\hline $\mathrm{T} 2-\mathrm{T} 1$ & $2.49 \pm 2.61$ & $4.11 \pm 3.18$ & 0.19 \\
\hline
\end{tabular}

*indicates $\mathrm{p}<0.05$

The groups were found to be similar regarding all cephalometric values at T1. The changes in ANSVR and Pr-VR values of the ANSR+ group were statistically smaller than the ANSR- group (ANSVR: 2.33 vs. 4.52 ; Pr-VR: 0.82 vs. 2.03 ) between $\mathrm{T} 2$ and $\mathrm{T} 1$.

Maxillary soft to hard tissue ratios in the ANSR+ group were smaller than those in the
ANSR- group. $\operatorname{Pr} / \mathrm{ANS}: 6 \%$ vs $49 \%, \operatorname{Pr} / \mathrm{A}: 16 \%$ vs $42 \%, \mathrm{Sn} / \mathrm{A}: 52 \%$ vs $66 \%$, Ls/U1: $31 \%$ vs $78 \%$. (Table 3).

Mandibulary soft to hard tissue ratios were as follows: $\mathrm{Li} / \mathrm{L} 1: 103 \%$ vs $101 \%, \mathrm{~B} / \mathrm{B}: 99 \%$ vs $129 \%$, and $\mathrm{Pg} / \mathrm{Pg}: 122 \%$ vs $120 \%$, in ANSR+ and ANSR-groups, respectively. (Table 3). 
Table 3. Correlations and soft to hard tissue movement ratios $(\mathrm{S} / \mathrm{H})$ in the ANSR+ and ANSR-groups.

\begin{tabular}{ccccc}
\hline ANSR+ Group & & & & \\
\hline Soft Tissue Variable & Hard Tissue Variable & $\mathrm{r}$ & $\mathrm{p}$ & $\mathrm{S} / \mathrm{H}$ \\
\hline Pr & ANS & 0.259 & 0.42 & 0.06 \\
Pr & A & 0.720 & $\mathbf{0 . 0 1 *}$ & 0.16 \\
Sn & A & 0.787 & $\mathbf{0 . 0 0 *}$ & 0.52 \\
Ls & U1 & 0.803 & $\mathbf{0 . 0 0 *}$ & 0.31 \\
Li & L1 & 0.923 & $\mathbf{0 . 0 0 *}$ & 1.03 \\
B' & B & 0.974 & $\mathbf{0 . 0 0 *}$ & 0.99 \\
Pg' & Pg & 0.985 & $\mathbf{0 . 0 0 *}$ & 1.22 \\
\hline ANSR- Group & & & & \\
\hline Pr & ANS & 0.482 & 0.11 & 0.49 \\
Pr & A & 0.534 & $\mathbf{0 . 0 7 *}$ & 0.42 \\
Sn & A & 0.472 & 0.12 & 0.66 \\
Ls & U1 & 0.840 & $\mathbf{0 . 0 0 *}$ & 0.78 \\
Li & L1 & 0.845 & $\mathbf{0 . 0 0 *}$ & 1.01 \\
B' & B & 0.969 & $\mathbf{0 . 0 0 *}$ & 1.29 \\
Pg' & Pg & 0.975 & $\mathbf{0 . 0 0 *}$ & 1.20 \\
\hline
\end{tabular}

*indicates $\mathrm{p}<0.05$

\section{DISCUSSION}

Unlike most similar studies in the literature, the maxillary step osteotomy was used in the current study. To our knowledge, this is the first study that evaluates the soft to hard tissue ratios in this osteotomy technique. And the present study revealed that the maxillary step technique supports the tip of the nose much more than the original Le Fort I. Soft to hard tissue ratios related to the nose tip were reported between $16 \%$ and $35 \%$ in the literature. ${ }^{6,722,23}$ Whereas, relatively high $\operatorname{Pr} /$ ANS and $\mathrm{Pr} / \mathrm{A}$ ratios $(49 \%, 42 \%$, respectively) were found in the ANSR-group of the current study. So, the maxillary step osteotomy technique can be preferred in patients with a nasal hump. Supporting our findings, in a recent study ${ }^{9}$, modified Le Fort I step osteotomy was found to be effective for improvement of paranasal flatness in maxillary deficiency.

The current study also showed that ANS reduction considerably affects the soft tissue response of the nose tip. Pr/ANS and Pr/A ratios in the ANSR- group, were quite higher than those in the ANSR+ group (Pr/ANS: 0.49 vs. 0.06; $\operatorname{Pr} / \mathrm{A}: 0.42$ vs. 0.16). So, the clinician should examine the preoperative nose profile well and decide whether ANS reduction should be administered or not. Also, it should be noted that these soft to hard tissue rates will vary based on the amount of ANS reduction.

Another finding of the current study is that ANS reduction has an impact not only on the nose tip but also on other soft tissues such as the upper lip and the subnasal region. In the ANSR-group, the upper lip to upper incisor ratio (Ls/U1) was $78 \%$, while this ratio is halved and becomes $31 \%$ in the ANSR+ group. This effect might have occurred via the musculus depressor septi nasi. When ANS is remained intact, the tip of nose is further supported anteriorly. This leads the columella plane to rotate in the anti-clockwise direction, ${ }^{24}$ and the musculus depressor septi nasi pulls the upper lip forward and upward. On the 
other hand, when ANS reduction is performed, the upper lip loses this support in the anterior direction.

Soft tissue ratios in the mandible were consistent with other studies in the literature..$^{6,725-28}$ The correlations of soft to hard tissue movement in the mandible were more reliable than in the maxilla. This can be explained by before mentioned variations in maxillary surgical techniques such as the amount of ANS reduction, osteotomy type, or the soft tissue techniques used.

The current study has some limitations. The major limitation is the limited number of patients. Because patients with differences in surgical techniques involving hard or soft tissue were excluded from the study. The patients with the same type of osteotomy, the same direction of movement (pure maxillary advancement and mandibular setback without vertical movement), the same additional soft tissue techniques, and the same fixation technique were recruited in the current study. This effort restricted the number of patients included. Another limitation is the lack of an original Le Fort I group, including the same adjunctive surgical techniques.

\section{CONCLUSIONS}

The maxillary step osteotomy technique may be useful in patients where it is desired to further support the nose tip in an anterior direction. ANS reduction process causes a quite decrease in the soft tissue response of the tip of the nose and the upper lip. Specific studies for each surgical technique with an adequate number of patients in the maxilla are still needed.

\section{ACKNOWLEDGMENT}

We thank Assist. Prof. Osman Demir for the statistical analysis.

\section{ÖZ}

Amaç: Yumuşak doku profilinin tahmini, ortognatik cerrahi planlamanın önemli bir parçasıdır. Cerrahi tekniklerdeki değişiklikler yumuşak doku yanıtını etkileyebilir. Bu çalışma, anterior nasal spina (ANS) redüksiyonlu veya redüksiyonsuz basamaklı maksiller osteotominin yumuşak doku yanıtı üzerindeki etkilerini belirlemeyi amaçlamıştır. Gereç ve Yöntemler: Çalışmaya basamaklı maksiller osteotomi ve bilateral sagittal split ramus osteotomisi kullanılarak, maksiller ilerletme ve mandibular geri alma cerrahisi uygulanan toplam 24 hasta (17 kadın, 7 erkek) dâhil edildi. Daha sonra ANS redüksiyon pozitif (ANSR+) ve negatif grup (ANSR-) olmak üzere iki alt grup oluşturuldu. Tüm hastalarda chin sütür ve V-Y kapama teknikleri kullanılmıştır. Ameliyat öncesi ve ameliyattan 6-8 ay sonra alınan lateral sefalometrik radyografiler arşivden topland. Yumuşak ve sert doku değişiklikleri, eşleştirilmiş T-testi kullanılarak değerlendirildi. Sert ve yumuşak doku hareketleri arasındaki korelasyonu belirlemek için Pearson korelasyon testi kullanıldı. Bulgular: ANSR+ grubunun maksiller yumuşak/sert doku oranları ANSR- grubundan daha düşüktü. ANSR+ ve ANSR- gruplarında oranlar Pr/ANS:\% 6'ya karşı \% 49, Pr/A:\% 16'ya karşı \% 42, Sn/A:\% 52'ye karş1 \% 66, Ls/ U1:\% 31'e karş1 \% 78 olarak bulunmuştur. Sonuçlar: Basamaklı maksiller osteotomi tekniği, burun ucunun anterior yönde daha fazla desteklenmesinin istendiği hastalarda faydalı olabilir. ANS redüksiyon işlemi, burun ucu ve üst dudağın yumuşak doku yanıtında azalmaya neden olur. Subnazal bölge nispeten daha az etkilenir. Anahtar kelimeler: Ortodonti, ortognatik cerrahi işlemler, sefalometri.

\section{REFERENCES}

1. Ackerman JL, Proffit WR, Sarver DM. The emerging soft tissue paradigm in orthodontic diagnosis and treatment planning. Clin Orthod Res 1999;2:49-52.

2. Proffit WR. Masters of esthetic dentistry: The soft tissue paradigm in orthodontic diagnosis and treatment planning: A new view for a new century. J Esthet Restor Dent 2000;12:46.

3. San Miguel Moragas J, Van Cauteren W, Mommaerts MY. A systematic review on soft-to-hard tissue ratios in orthognathic surgery part I: maxillary repositioning osteotomy. J Craniomaxillofac Surg 2014;42:1341-1351.

4. Khamashta-Ledezma L, Naini FB. Prospective assessment of maxillary advancement effects: maxillary incisor exposure, and upper lip and nasal changes. Am J Orthod Dentofacial Orthop 2015;147:454-464.

5. Peled M, Ardekian L, Krausz AA, Aizenbud D. Comparing the effects of $\mathrm{V}-\mathrm{Y}$ advancement versus simple closure on upper lip aesthetics after Le Fort I advancement. J Oral Maxillofac Surg 2004;62:315-319. 6. Chew MT. Soft and hard tissue changes after bimaxillary surgery in Chinese Class III patients. Angle Orthod 2005;75:959-963. 
7. Altug-Atac AT, Bolatoglu H, Memikoglu UT. Facial soft tissue profile following bimaxillary orthognathic surgery. Angle Orthod 2008;78:50-57.

8. Aydil B, Ozer N, Marsan G. Bimaxillary surgery in Class III malocclusion: soft and hard tissue changes. J Craniomaxillofac Surg 2013;41:254-257.

9. Catherine Z, Scolozzi P. Modified Le Fort I step osteotomy for improvement of paranasal flatness in maxillary deficiency: Technical note and series of 24 cases. J Stomatol Oral Maxillofac Surg 2019;120:559565.

10. Keller EE, Sather AH. Intraoral quadrangular Le Fort II osteotomy. J Oral Maxillofac Surg 1987;45:223232.

11. Obwegeser HL. Surgical correction of small or retrodisplaced maxillae. The "dish-face" deformity. Plast Reconstr Surg 1969;43:351-365.

12. Kufner J. Four-year experience with major maxillary osteotomy for retrusion. J Oral Surg 1971;29:549-553.

13. Kaminishi RM, Davis WH, Hochwald DA, Nelson N. Improved maxillary stability with modified Lefort I technique. J Oral Maxillofac Surg 1983;41:203-205.

14. Bennett MA, Wolford LM. The maxillary step osteotomy and Steinmann pin stabilization. J Oral Maxillofac Surg 1985;43:307-311.

15. Stringer DE, Boyne PJ. Modification of the maxillary step osteotomy and stabilization with titanium mesh. J Oral Maxillofac Surg 1986;44:487-488.

16. Olate S, Zaror C, Blythe JN, Mommaerts MY. A systematic review of soft-to-hard tissue ratios in orthognathic surgery. Part III: Double jaw surgery procedures. J Craniomaxillofac Surg 2016;44:15991606.

17. Shoji T, Muto T, Takahashi M, Akizuki K, Tsuchida Y. The stability of an alar cinch suture after Le Fort I and mandibular osteotomies in Japanese patients with Class III malocclusions. Br J Oral Maxillofac Surg 2012;50:361-364.

18. Schendel SA, Williamson LW. Muscle reorientation following superior repositioning of the maxilla. J Oral Maxillofac Surg 1983;41:235-240.
19. Legan HL, Burstone CJ. Soft tissue cephalometric analysis for orthognathic surgery. J Oral Surg 1980;38:744-751.

20. Lew K, Loh F, Yeo J, Loh H. Evaluation of soft tissue profile following intraoral ramus osteotomy in Chinese adults with mandibular prognathism. Int J Adult Orthodon Orthognath Surg 1990;5:189-197.

21. Dahlberg G. Statistical methods for medical and biological students. Statistical methods for medical and biological students. 1940 .

22. Louis PJ, Austin RB, Waite PD, Mathews CS. Soft tissue changes of the upper lip associated with maxillary advancement in obstructive sleep apnea patients. J Oral Maxillofac Surg 2001;59:151-156.

23. Soncul M, Bamber MA. Evaluation of facial soft tissue changes with optical surface scan after surgical correction of Class III deformities. J Oral Maxillofac Surg 2004;62:1331-1340.

24. Davidson E, Kumar AR. A Preliminary ThreeDimensional Analysis of Nasal Aesthetics Following Le Fort I Advancement in Patients With Cleft Lip and Palate. J Craniofac Surg 2015;26:629-633.

25. Kaklamanos EG, Kolokitha O-E. Relation between soft tissue and skeletal changes after mandibular setback surgery: a systematic review and meta-analysis. J Craniomaxillofac Surg 2016;44:427-435.

26. Lin SS, Kerr WJ. Soft and hard tissue changes in Class III patients treated by bimaxillary surgery. Eur J Orthod 1998;20:25-33.

27. Jensen AC, Sinclair PM, Wolford LM. Soft tissue changes associated with double jaw surgery. Am J Orthod Dentofacial Orthop 1992;101:266-275.

28. 28. Becker OE, Avelar RL, Dolzan Ado N, Haas OL, Jr., Scolari N, Oliveira RB. Soft and hard tissue changes in skeletal Class III patients treated with double-jaw orthognathic surgery-maxillary advancement and mandibular setback. Int $\mathbf{J}$ Oral Maxillofac Surg 2014;43:204-212. 